\title{
KEEP CALM AND ... UNDERSTAND CANNABIS: WHAT EMPLOYERS IN THE ENERGY SECTOR WANT TO KNOW ABOUT LEgalized CANNABIS IN THE WORKPLACE
}

\author{
SHANA WOLCH, ${ }^{*}$ JUSTINE LINDNER, ${ }^{* *}$ \\ DAN DEMERS, ${ }^{* * *}$ AND BEN RATELBAND ${ }^{* * * *}$
}

\begin{abstract}
With the recent legalization of recreational cannabis in Canada, employers, particularly those with safety sensitive operations, are forced to evaluate the impact that cannabis will have on their workplaces. This article argues that the law has not yet fully evolved with the advances in scientific understanding of the effects of cannabis or the advances in the technology for testing methodologies. The article explores the current legal framework for workplace drug testing and provides best practices regarding drug testing programs and related workplace policies. It cautions that unless carefully designed, these policies may be found to be contrary to human rights or privacy legislation, or, in the case of unionized employers, unreasonable and outside the scope of the collective agreement.
\end{abstract}

\section{TABLE OF CONTENTS}

I. INTRODUCTION . . . . . . . . . . . . . . . . . . . . . . . . . . . . . . 337

II. The Legalization OF CANNABIS $\ldots \ldots \ldots \ldots \ldots \ldots \ldots \ldots \ldots \ldots \ldots \ldots$

III. CAnNabis In the WorkPlace: The Legal FrameWork $\ldots \ldots \ldots . . .341$

A. FitNess For Duty (SAFETy SENSITIVE Versus

Non-SAfety Sensitive Positions) . . . . . . . . . . . . . . . . . . . . 342

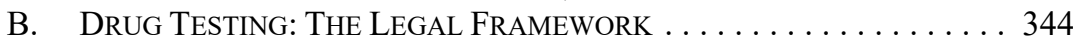

C. JustificATIONS FOR TESTING $\ldots \ldots \ldots \ldots \ldots \ldots \ldots \ldots \ldots \ldots \ldots$

D. IMPLICATIONS FOR EMPLOYERS IN THE ENERGY SECTOR . . . . . . . . 354

IV. Medical CAnnabis Considerations $\ldots \ldots \ldots \ldots \ldots \ldots \ldots \ldots \ldots \ldots \ldots$

A. Medical Cannabis at the WorkPlace $\ldots \ldots \ldots \ldots \ldots \ldots . \ldots \ldots 6$

V. RECREATIONAL CANNABIS CONSIDERATIONS ................ 359

VI. Is a Zero Tolerance Policy Acceptable? . . . . . . . . . . . . . 360

VII. POLICIES REQUIRING Disclosure

OF SUBSTANCE DePENDENCY . . . . . . . . . . . . . . . . . . . . . . . 361

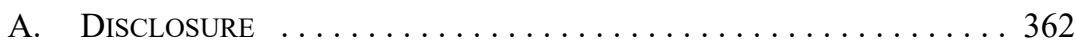

VIII. CONCLUDING REMARKS:

WHAT tO EXPECT FROM FUtURE LEGISLATION . . . . . . . . . . . . . . 364

\section{INTRODUCTION}

With the federal government's recent legalization of recreational cannabis use in Canada, employers are forced to evaluate the impact that cannabis will have on their workplaces. These considerations are of particular concern to organizations in the energy sector, many having operations that are safety sensitive and require uncompromised workplace health and safety programs.

* $\quad$ Partner, McCarthy Tétrault LLP, Calgary.

*** Associate, McCarthy Tétrault LLP, Toronto.

*** Director Business Development, C-SAPA (Certified Substance Abuse Program Administrator), North Bay, Ontario.

***** Partner, McCarthy Tétrault LLP, Toronto. 
Canadian law requires a weighing of an individual's rights to privacy and human rights against an employer's obligation to take specific measures to ensure its workplace is healthy and safe. Given the heightened importance of safety in the high risk working environments of the energy sector, these employers are often on the front line for worker drug testing and the enforcement of bans of possession and use of drugs on work sites.

A review of the current Canadian framework for workplace drug testing demonstrates that the law and scientific understanding of the effects of cannabis need to evolve with the advances in the technology for testing methodologies.

By exploring the practical impact of recent Canadian appellate decisions on workplace policies and practices, and applying existing legal principles to scientific and technological advances, conclusions can be drawn regarding the types of changes that can be expected in Canadian law moving forward, including the likelihood of certain drug testing programs being upheld. The requirements set out by industry governing bodies and regulators, as well as the positions advanced by employer organizations, also provide useful direction for employers seeking to uphold workplace drug testing policies.

This article intends to provide both awareness and best practices when it comes to the enforceability of drug testing programs and related workplace policies in the wake of the new legal, green landscape.

\section{The Legalization of Cannabis}

Throughout this article, we will refer to "cannabis" instead of the term "marijuana" or other names indigenous to local cultures, and delta-9-tetrahydrocannabinol, commonly known as "THC," the most predominant psychoactive compound of the 104 known "cannabinoids." The World Health Organization defines these terms as follows:

Cannabis. A generic term used to denote the several psychoactive preparations of the cannabis plant. Cannabis is the preferred designation of the plant Cannabis sativa, Cannabis indica and, of minor significance, Cannabis ruderalis.... Cannabis resin means "separated resin", whether crude or purified, obtained from the cannabis plant... Cannabis preparations are usually obtained from the female Cannabis sativa plant. The plant contains at least 750 chemicals and some 104 different cannabinoids... The principal cannabinoids in the cannabis plant include delta-9-tetrahydrocannabinol (THC), cannabidiol (CBD), and cannabinol $(\mathrm{CBN}){ }^{1}$

Cannabinoids: Cannabinoids are a class of diverse chemical compounds that act on cannabinoid receptors in cells that modulate neurotransmitter release in the brain. The composition, bioavailability, pharmacokinetics and pharmacodynamics of botanical cannabis differ from those of extracts of purified individual cannabinoids. Cannabinoids are basically derived from three sources: (a) phytocannabinoids are cannabinoid compounds produced by plants Cannabis sativa or Cannabis indica; (b) endocannabinoids are neurotransmitters produced in the brain or in peripheral tissues, and act on cannabinoid receptors; and (c) 
synthetic cannabinoids, synthesized in the laboratory, are structurally analogous to phytocannabinoids or endocannabinoids and act by similar biological mechanisms. ${ }^{2}$

The scope of discussion on cannabinoids in this article is limited to phytocannabinoids.

On 21 June 2018, An Act respecting cannabis and to amend the Controlled Drugs and Substances Act, the Criminal Code and other Acts ${ }^{3}$ (referred to also as Bill C-45 or the Cannabis Act), received royal assent and became law in Canada. The Cannabis Act, which legalizes recreational cannabis use by removing the relevant provisions of Canada's Criminal Code, came into force such that legal sales commenced on 17 October 2018. ${ }^{4}$ While this federal legislation decriminalizes recreational cannabis sales and use, the determination of provincial rules with respect to the implementation of the legalization of cannabis have been left to the provincial and territorial governments.

Since the federal government's initial announcement regarding the legalization of cannabis, much of the relevant media coverage has addressed the sale, distribution, and rules of consumption of cannabis with minimal discussion of the obvious risks that cannabis use can pose to workplace safety. While the safety hazards that cannabis presents on our roads and at our workplaces is not new, it is important to understand that the size of this risk will only grow with legalization. Employers with safety sensitive workplaces, where employees are required to use dangerous equipment, work at heights, or are responsible for having a strong executive function to ensure that their work is performed safely for themselves, their co-workers, and the public, are particularly concerned with the potential impact that the legalization of cannabis will have on their workforces.

For context, cannabis appears to be a mainstream drug for Canadians, its reported use following only alcohol and tobacco. In 2018, an estimated 4.6 million individuals aged 15 and over will use cannabis at least once, and by 2021 this number could rise to 5.2 million. ${ }^{5}$

In Colorado and Washington, the first American states in which recreational cannabis use was legalized, the overall urine positivity rate for cannabis testing in dangerous occupational settings, with preventative and reactionary provisions to ensure fitness for duty, outpaced the national average in 2016 for the first time since the statutes legalizing cannabis took effect. The increase was more pronounced in Colorado, which increased by 11 percent $(2.61$ percent in 2015 versus 2.90 percent in 2016), than in Washington, which increased by 9 percent $(2.82$ percent in 2015 versus 3.08 percent in 2016). The national positivity rate for cannabis in the general United States workforce in urine testing increased four percent (2.4 percent in 2015 compared to 2.5 percent in 2016). ${ }^{6}$

Ibid.

SC 2018, c 16

Cannabis Regulations, SOR/2018-144.

Canada, Office of the Parliamentary Budget Officer, Legalized Cannabis: Fiscal Considerations (Ottawa: PBO, 1 November 2016) at 1.

Quest Diagnostics, "Increases in Illicit Drugs, Including Cocaine, Drive Workforce Drug Positivity to Highest Rate in 12 Years, Quest Diagnostics Analysis Finds" (16 May 2017), online: <www.quest diagnostics.com/dms/Documents/Employer-Solutions/Brochures/quest-diagnostics-drug-testing-index2017-press-release.pdf $>$. 
This evidence suggests that Canadian employers in complex safety sensitive industries are vulnerable to anticipated increased cannabis use following legalization.

There is no dispute that cannabis use has been and will continue to be a safety hazard faced by Canadian employers in the energy sector. An employer's success in mitigating this risk is directly tied to the ability to deter employees from the use of any substance that has the potential to impair performance.

The truth about cannabis must be untangled from the myths before a reasonable balance can be struck between safety, security, and other legal regimes, including those that govern privacy, human rights, and employment and labour.

Regarding legalized mind or mood altering substances, employers are familiar with addressing alcohol and its impairing effects. Unlike alcohol however, which wears off after some time, impairment from cannabis can have lasting effects that persist up to and beyond 24 hours. $^{7}$ Cannabis is not only impairing during a period of acute intoxication or when a person would be commonly referred to as being "high," but it can continue to impair functionality for unspecified periods of time.

In fact, performance can be impaired for as long as 24 hours after consuming a moderate dose of cannabis, and the user may actually be unaware of its continued influence. In addition, recently abstinent cannabis users (seven hours to 20 days), could experience impairment in attention, concentration, inhibition, impulsivity, and executive function during the period of time in which THC and its metabolites are still being eliminated from the individual's body. The more prolonged the use of cannabis, the greater the residual deficits in these types of functioning following abstinence. ${ }^{8}$

In his review for the Construction Labour Relations of Alberta, entitled "Marijuana and the Safety-Sensitive Worker," author Brendan Adams concludes that cannabis impairs the ability of individuals to perform safety sensitive duties for periods of time that are highly variable, but which will be longer than the period of acute intoxication and that there is no particular level of blood concentration of THC which can be identified below which safety impairment is not a concern. ${ }^{9}$ Recently the Occupational and Environmental Association of

See Government of Canada, "Health Effects of Cannabis" (2017), online: <https://www.canada.ca/ content/dam/hc-sc/documents/services/campaigns/27-16-1808-Factsheet-Health-Effects-eng-web.pdf>; Bertha K Madras, Update of Cannabis and its Medical Use (Geneva: World Health Organization, 2015). See also Health Canada, Information for Health Care Professionals: Cannabis (Marihuana, Marijuana) and the Cannabinoids (Ottawa: Health Canada, February 2013) at 79 [Health Canada, Information for Health Care Professionals].

Government of Canada, "Health Effects of Cannabis," ibid ; WHO, Effects of Nonmedical Cannabis Use, supra note 1; The College of Family Physicians of Canada, "The College of Family Physicians of Canada Statement on Health Canada's Proposed Changes to Medical Marijuana Regulations" (February 2013), online: $<$ https://www.cfpc.ca/uploadedFiles/Health_Policy/CFPC_Policy_Papers and Endorse

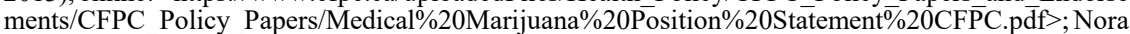
D Volkow et al, "Adverse Health Effects of Marijuana Use" (2014) 370:23 New Eng J Med 2219; Igor Grant et al, "Non-acute (Residual) Neurocognitive Effects of Cannabis Use: A Meta-Analytic Study" (2003) 9:5 J Intl Neuropsychological Society 679; Krista Lisdahl Medina et al, "Neuropsychological Functioning in Adolescent Marijuana Users: Subtle Deficits Detectable After a Month of Abstinence" (2007) 13:5 J Intl Neuropsychological Society 807.

9 Brendan Adams, Construction Labour Relations of Alberta, "Marijuana and the Safety Sensitive Worker" (2016), online: <https://www.clra.org/p/marijuana+and+the+safety+sensitive+worker>. 
Canada released its "Position Statement on the Implications of Cannabis Use for SafetySensitive Work" in which it has conclusively stated that it is not advisable to engage in safety sensitive tasks for 24 hours following Cannabis consumption. ${ }^{10}$

There are many claims that individuals using cannabidiol (CBD) formulations are fit for duty and can perform safety sensitive work. Such formulations of cannabis are understood as having high CBD content relative to THC. Some of these preparations have very low concentrations of THC (less than 1 percent), which is why they are not commonly viewed as causing impairment. ${ }^{11}$ However, a percentage is not a dose; large, frequently ingested amounts can still pose a material risk. CBD is not a drug or medication approved by Health Canada. ${ }^{12}$ Nonetheless, with more time and research, isolated CBD might become a viable alternative to consuming cannabis with higher percentages of THC, particularly for medicinal use.

Currently, the most recent scientific studies and reviews on cannabis use do not provide employers of safety sensitive employees with sufficient comfort to identify thresholds of $\mathrm{THC}, \mathrm{CBD}$, or other psychoactive cannabinoids in cannabis for safety sensitive work, which is of particular concern to employers in the energy sector.

\section{CANNABis in the WorkPlace: THE LEGAL FrAMEWORK}

On Christmas Eve of 2009, five workers fell from the 14th floor of a high rise apartment building in Toronto when the swing stage they were working on collapsed. ${ }^{13}$ Four workers died, with the fifth worker surviving the fall with serious injuries. The subsequent investigation into this incident by the Ontario Ministry of Labour found that there were a number of contributing factors to the incident, including several egregious violations of applicable health and safety law in relation to the swing stage and the failure to provide an adequate number of lifelines. The employer, Metron Construction, was the first corporation in Canada to plead guilty to criminal negligence causing death under the Criminal Code in June 2012 and was fined $\$ 200,000 .{ }^{14}$ The fine was subsequently overturned by the Ontario Court of Appeal, which instead imposed a fine of $\$ 750,000 .{ }^{15}$ The construction project manager was found guilty of five counts of criminal negligence and was sentenced to 3.5 years in prison for each of the five convictions of criminal negligence, with the sentences to

Occupational and Environmental Medical Association of Canada, "Position Statement on the Implications of Cannabis Use for Safety-Sensitive Work" (Winnipeg: OEMAC, 24 September 2018), online: <https://oemac.org/wp-content/uploads/2018/09/Position-Statement-on-the-Implications-ofcannabis-use.pdf $>$.

11 See Health Canada, Information for Health Care Professionals, supra note 7 at 47, 79; World Health Organization, Expert Committee on Drug Dependence, Cannabidiol (CBD): Pre-Review Report, 39th meeting (Geneva: WHO, November 2017), online: <www.who.int/medicines/access/controlledsubstances/5.2 CBD.pdf>.

12 Health Canada, Information for Health Care Professionals, ibid; Canada, "Access to Cannabis for Medical Purposes Regulations - Daily Amount Fact Sheet (Dosage)" (July 2016), online: < https://www. canada.ca/en/health-canada/services/drugs-medication/cannabis/information-medical-practitioners/ cannabis-medical-purposes-regulations-daily-amount-fact-sheet-dosage.html $>$.

$13 \quad R v$ Metron Construction Corporation, 2012 ONCJ 506 [Metron CJ], rev'd 2013 ONCA 541 [Metron CA].

Ibid.

Ibid. 
be served concurrently. ${ }^{16}$ One significant factor that is not always addressed in discussions of these precedent setting decisions respecting criminal negligence is that three of the deceased workers, one of which had been the site supervisor, were found to have had levels of cannabis in their systems consistent with recent use. ${ }^{17}$

Although cannabis impairment in the workplace is not a new issue, the legalization of recreational cannabis in 2018 has spurred regulators to intensify their focus on workplace health and safety. ${ }^{18}$ While legislators devise and implement further regulatory guidelines, employers must operate in accordance with the current legal framework to address the risk of impairment in the workplace.

\section{A. Fitness For Duty (SAfety Sensitive Versus Non-Safety Sensitive Positions)}

At law, safety in the workplace is a shared responsibility imposed on a range of stakeholders with distinct yet complementary duties and interests. ${ }^{19}$ While employers bear "primary responsibility to develop and maintain adequate safety measures at [their] work sites, because [they have] the greatest control over circumstances there," ${ }^{20}$ workers must nevertheless "protect themselves and each other." 21 Because liability for safety in the workplace is joint and several, failure on the part of employers in respect of their duties does not relieve employees of their own obligations ${ }^{22}$ — in all circumstances employees must report to work in a fit, uncompromised condition.

Although the concept of "fitness for duty," also referred to as "fitness to work," has become a central theme of occupational health and safety programs in recent years, no authoritative definition for this concept has been adopted across jurisdictions or industries. ${ }^{23}$ Broadly speaking, fitness for duty refers to a physical, psychological, and emotional state that allows an individual to perform a job or task in a manner that does not compromise or

$R v$ Vadim Kazenelson, 2015 ONSC 3639, aff’d 2018 ONCA 77 [Kazenelson CA]; Rv Kazenelson, 2016 ONSC 25, aff'd Kazenelson CA, ibid.

Metron CJ, supra note 13 at para 6.

At the federal level, see Government of Canada, A Framework for the Legalization and Regulation of Cannabis in Canada: The Final Report of the Task Force on Cannabis Legalization and Regulation (Ottawa: Health Canada, 30 November 2016) at 28-29 [Government of Canada, Framework for Legalization and Regulation].

The statutory duties of workplace stakeholders vary across jurisdictions. While the Ontario Occupational Health and Safety Act, RSO 1990, c O.1 [Ont OSHA] lists the duties ascribed to constructors, licensees, employers, supervisors, workers, owners, project owners, suppliers, and directors and officers of corporations (ss 23-32), the Canada Labour Code, RSC 1985, c L-2, only expressly addresses the duties of employers and employees (ss 122-60). In Alberta, following a comprehensive review of the province's occupational health and safety framework in 2017, the Occupational Health and Safety Act, SA 2017, c O-2.1 was amended to, among other things, expand the workplace safety obligations expressly addressed in the statute to a wider range of stakeholders including suppliers, services providers, owners, contractors, prime contractors, self-employed persons, and temporary staffing agencies (ss 3-13).

$R v$ Campbell (2006), 140 CRR (2d) 143 (Ont Sup Ct J) [Campbell Sup Ct], aff'g Rv Campbell, [2004] OJ No 129 (QL) (Ct J) [Campbell Ct J]. Campbell Ct J, ibid at para 86.

Ibid at para 71, citing $R$ v Stelco Inc, [1989] OJ No 3122 (QL) (Ct J (Prov Div)). See also Ontario (Ministry of Labour) v Black \& McDonald Ltd (2009), 83 CRL (3d) 44 (Ont Sup Ct) at para 68, rev'd 2011 ONCA 440.

The Canadian Centre for Occupational Health and Safety defines fitness to work as "a medical assessment done when an employer wishes to be sure an employee can safely do a specific job or task": Canadian Centre for Occupational Health and Safety, "OSH Answers Fact Sheets: Fit to Work" (1 April 2016), online: <https://www.ccohs.ca/oshanswers/psychosocial/fit_to_work.html >. 
threaten the safety or health of that individual, others, property, or the environment. This proposed definition hinges on two important elements: capacity and task specificity.

To begin, fitness for duty concerns a worker's capacity to perform job related tasks, as opposed to his or her actual performance or conduct. An underperforming or unproductive individual may be capable of performing his or her job safely and effectively but might just be unwilling to do so for a variety of reasons usually addressed by traditional performance management and progressive disciplinary measures. By contrast, another individual may similarly be underperforming and be unable to adequately carry out his or her duties as a result of disability, such as addiction, which should be addressed in accordance with the company's applicable accommodation policy and procedure.

Secondly, fitness for duty is task specific. As confirmed by the Nova Scotia Court of Appeal, "[t]he medical judgment of fitness for work is not dispositive unless linked to a specific set of job duties which constitute the 'regular duties' of the claimant's occupation." 24 Like all responsibilities underlying occupational health and safety, an employee's responsibility to be fit for duty is commensurate to, among other things, the nature of the work and the circumstances of the workplace. ${ }^{25}$

Finally, while all employees are expected to be fit for duty, individuals in positions involving heightened risks may justifiably be held to a higher standard. Often designated as "safety sensitive," these positions have regard to such factors as the particular dangerous environment where the work is performed, the equipment utilized, and the employee's direct involvement in high-risk operations, including working from heights, and are such that impairment could result in significant property or environmental damage, or injury to the employee, others in the workplace, or the public. ${ }^{26}$ Safety sensitive positions often depend on alertness, quickness of response, soundness of judgment, and accuracy of coordination of multiple muscle and cognitive functions.

Determining whether a position is safety sensitive requires a holistic assessment of both the likelihood that risks of damage or injury may materialize and the magnitude of potential loss. ${ }^{27}$ In a recent decision, an arbitrator concluded that labourer level positions on a construction project which involved working occasionally with motorized equipment in close proximity to larger pieces of heavy equipment in demanding field and weather conditions 47.

25 Campbell Sup Ct, supra note 20 at para 4.

26 Canadian National Railway and CAW, Local 100 (Workplace Alcohol and Drug Policy), Re (2010), 2010 CarswellNat 6164 (WL Can) at para 5 (Arbitrator: Michel G Picher); Canadian Human Rights Commission, Impaired at Work: A Guide to Accommodating Substance Dependence (Ottawa: CHRC, 2017) at 4, online: <https://www.chrc-ccdp.gc.ca/sites/default/files/impaired_at_work.pdf>. See also Entrop v Imperial Oil Ltd (2000), 50 OR (3d) 18 (CA) [Entrop], in which Imperial Oil's policy under review designated that safety sensitive positions were those "where impaired performance could result in a catastrophic incident" and "no direct or very limited supervision [is] available to provide frequent operational checks" (ibid at para 6 [emphasis added]).

27 See Communications, Energy and Paperworks Union, Local 707v Suncor Energy Inc, 2012 ABCA 373 at para 19 , Côté JA, dissenting. 
were safety sensitive, as the positions demanded the worker's undivided focus and a high level of mental alertness to ensure safety. ${ }^{28}$

In keeping with their statutory duty to provide a safe workplace, employers, including managers and supervisors, are required to take reasonable precautions to ensure the fitness for duty of employees under their control, whether on a permanent, interim, or temporary basis, at the start of, and throughout, each work period.

Adopting a fitness for duty standard is inherently discriminatory as it will preclude an individual with a substance dependence disorder from employment. Human rights legislation in Canada generally prohibits discrimination or perceived discrimination on the basis of a prohibited ground, including disability, where there is an adverse consequence to an employee. ${ }^{29}$ In general, exceptions may be available when a discriminatory standard is a bona fide (good faith) occupational requirement. ${ }^{30}$ Where a job requires an employee to be fit for duty for legitimate safety reasons, this exception may be available to the employer.

As a starting place, employees in safety sensitive positions should be prohibited from working or even remaining in the workplace while their ability to work is affected by alcohol, drugs, or other substances in a manner that endangers their health or safety or that of any other person. ${ }^{31}$ Employers should implement applicable policies and should also consider drug testing as part of the overall safety due diligence program. Whether a particular drug testing policy is likely to withstand judicial scrutiny will depend on the safety sensitive nature of the identified positions and the circumstances of the workplace. ${ }^{32}$

\section{B. Drug Testing: The Legal Framework}

The legality of drug and alcohol testing policies is often challenged. Unless carefully designed, such policies may be found to be contrary to human rights or privacy legislation, ${ }^{33}$ or, in the case of unionized employers, unreasonable and outside the scope of the collective agreement. $^{34}$

Drug testing is typically used as a risk management tool in an employer's broader safety system to mitigate risk related to the effects of drugs and alcohol on workplace safety. The objective of a drug test is not necessarily to identify impairment; instead, it is to conclusively identify drug usage that poses an unacceptable risk for the occupational activities in question,

International Brotherhood Lower Churchill Transmission Construction Employers'Assn Inc and IBEW, Local 1620 (Tizzard), Re (2018), 2018 CarswellNfld 198 (WL Can) at paras 132-35 (Arbitrator: John F Roil) [Tizzard].

Canadian Human Rights Act, RSC 1985, c H-6, s 10.

Ibid, s 15.

Occupational Health and Safety Regulation, BC Reg 296/97, s 4.20; Occupational Health and Safety Regulations, YOIC 2006/178, s 1.05 .

32 See e.g. Entrop, supra note 26; Communications, Energy and Paperworkers Union of Canada, Local 30 v Irving Pulp \& Paper, Ltd, 2013 SCC 34 [Irving]; Imperial Oil Ltd v Communications, Energy \& Paperworkers Union of Canada, Local 900, 2009 ONCA 420 [Nanticoke].

33 It should be noted that each Canadian jurisdiction has enacted its own human rights legislation. It cannot be assumed that the jurisprudence from one province is applicable in another or at the federal level.

They could also result in constructive or wrongful dismissal claims if a newly implemented policy during the tenure of an employee constitutes a fundamental or significant change to the terms of employment. 
this use possibly being indicative of impairment of the individual's ability to perform work safely. Biological mediums for testing include urine, oral fluid (saliva), and hair testing. ${ }^{35}$ Workplace drug testing methods will usually be in the form of either urinalysis or oral swab.

The process of drug testing generally starts with the documentation of a chain of custody form $(\mathrm{CCF})$ that ensures the continuity, integrity, and privacy of the process. The collection of the specimen (urine or oral fluid) is performed by a certified collection agent in a controlled and confidential environment where the opportunities to tamper with the sample are reduced. ${ }^{36}$

Accredited testing laboratories by the Substance Abuse and Mental Health Services Administration (SAMHSA) require extensive procedures for the handling, quality assurance, and defensibility of the final result. ${ }^{37}$ These measures include running all testing on approved instruments, including quality assurance samples, and testing to the established detection limits. These detection limits are called "cut-off levels," and they are essential to ensuring that passive inhalation of a drug would not produce a positive confirmed laboratory result. ${ }^{38}$ There are two instrumentation methods used in the laboratory to confirm whether a final result is positive.

The final positive laboratory result is then reported to a medical review officer (MRO). ${ }^{39}$ The MRO plays a vital role in the final stage of the process where the individual who provided the sample is contacted to discuss the result, answer questions related to use, and determine if any legitimate prescriptions could have resulted in the outcome. The MRO should be a licensed physician, in good standing with the college, with specialized training and certification including with respect to interpreting results and all of the potentially valid prescription explanations for those results. The typical outcome from the MRO interview is a reported verified positive test, with or without contact, or a reported verified negative result, with or without a safety advisory. The MRO can report a laboratory result after a set period has elapsed without successful contact, and after a certain number of attempts have been made to reach the individual who had provided the sample. ${ }^{40}$

The MRO may identify a valid prescription that caused the laboratory positive test result that poses a risk to workplace safety. In this instance, a negative result with a safety advisory result would be reported to the employer, obligating the employer to ensure it has obtained from the individual a proper clearance from the prescribing physician before performing any safety sensitive activities. The prescribing physician should be informed of the nature of the

It is important to note that to establish a reasonable connection to risk in the workplace, hair testing is not recommended as a medium of testing: Construction Owners Association of Alberta \& Energy Safety Canada, "Canadian Model for Providing a Safe Workplace: A Best Practice Guide," version 6.0 (Edmonton: COAA, 1 July 2018) at 2, E-7-E-8, online: <https://www.coaa.ab.ca/COAA-Library/SAFCDM-CBP-01-2018-v6\%20Canadian\%20Model.pdf> [COAA, "Best Practice Guide"]; Norm Keith, "Alcohol and Drugs in the Canadian Workplace," 2nd ed (Toronto: LexisNexis Canada, 2015) at 92-94. CFR tit 49 § 40 (2017); COAA, "Best Practice Guide," ibid at 10.

CFR, ibid, §§ 40.81-40.113; COAA, "Best Practice Guide," ibid.

CFR, ibid; COAA, "Best Practice Guide," ibid at E-8; Department of Health and Human Services, "Medical Review Officer Guidance Manual for Federal Workplace Drug Testing Programs" (Rockville: SAMHSA, 1 October 2017) at 4-8, 7-6-7-7; Mandatory Guidelines for Federal Workplace Drug Testing Programs, 82 Fed Reg 7920 (2017), § 13.5. 
occupation by reviewing a full detailed job description, and should have knowledge of both the employee's and the employer's occupational health and safety obligations.

There are alternative non-laboratory testing technologies available for drug testing. These tests are called point of collection tests (POCT) and must align with the established standards for laboratory cut-off levels, and be performed with specificity and precision. ${ }^{41}$ At this time, using urine POCT is commonly accepted, provided that there is laboratory confirmation of the result and an ensuing MRO review of all non-negative or inconclusive outcomes. Options for oral fluid instant testing devices that align with the established cut-off levels for drug testing remain limited. ${ }^{42}$

\section{HUMAN RighTS}

Drug and alcohol testing engages human rights law because jurisprudence has recognized substance dependency as a disability, which is a prohibited ground of discrimination. ${ }^{43}$ To challenge drug and alcohol screening under human rights legislation, an employee must first establish a "prima facie case of discrimination" on the basis of substance dependency. If the employee passes this threshold, the onus shifts to the employer to demonstrate that the impugned policy is a "bona fide occupational requirement" (often referred to as a BFOR).

The test for establishing prima facie discrimination was recently considered by the Supreme Court of Canada in Stewart. ${ }^{44}$ On appeal of this Alberta case, the Supreme Court held that employees seeking to establish prima facie discrimination must demonstrate that:

1. they possess a characteristic protected from discrimination under the provincial human rights statute;

2. they experienced an adverse impact; and

3. the protected characteristic was a factor in the adverse impact. ${ }^{45}$

A prima facie case of discrimination will not be established if any of the criteria listed above are not proven on a balance of probabilities. For example, the employer might rebut the third criterion by demonstrating that substance dependency was not a causal factor in the employee's misconduct. ${ }^{46}$

CFR, ibid; COAA, "Best Practice Guide," ibid.

Dan Demers, "The Truth About Instant Oral Fluid Testing” (April 2012), online: <https://www. cannamm.com/wp-content/uploads/2013/12/Whitepaper-OralInstantFluid.pdf>;OlafH Drummer, "Drug Testing in Oral Fluid" (2006) 27:3 Clinical Biochemist Rev 147.

See e.g. Stewart v Elk Valley Coal Corp, 2017 SCC 30 at para 22 [Stewart]; Entrop, supra note 26 at para 89; Mainland Sawmills and IWA-Canada, Loc 2171 (Kandola) (Re) (2002), 104 LAC (4th) 385 at 398 (Arbitrator: B Foley).

Stewart, ibid at paras 23-24.

Ibid at 24.

See e.g. British Columbia (Public Service Agency) v BCGEU, 2008 BCCA 357. In Stewart, ibid, the majority held that the Tribunal's decision that Stewart had not made out a prima facie case of discrimination was reasonable. The employer's position that Stewart was terminated for failing to comply with his employer's Alcohol, Illegal Drugs \& Medication Policy, and not for any discriminatory reason, was supported by Stewart's termination letter. Justices Wagner and Moldaver, concurring in the result, and Justice Gascon, dissenting, found that a prima facie case of discrimination had been established. 
Once a prima facie case of discrimination is established, the employer may demonstrate a BFOR by proving on a balance of probabilities that:

1. the employer adopted the standard for a purpose rationally connected to the performance of the job;

2. the employer adopted the particular standard in an honest and good faith belief that it was necessary to the fulfilment of that legitimate work related purpose; and

3. the standard is reasonably necessary to the accomplishment of that legitimate work related purpose. ${ }^{47}$

To meet the third criterion, the employer must demonstrate that individual employees cannot be accommodated without imposing undue hardship on the employer. Even where there are potentially significant health and safety issues, the threshold of "undue hardship" is high. As explained by the Supreme Court of Canada in Meiorin:

[T] he use of the term "undue" infers that some hardship is acceptable; it is only "undue" hardship that satisfies this test.... [T] he standard, if it is to be justified under the human rights legislation, must accommodate factors relating to the unique capabilities and inherent worth and dignity of every individual, up to the point of undue hardship. ${ }^{48}$

In the recent decision of Tizzard ${ }^{49}$ which is helpful to employers, the arbitrator dismissed a grievance that challenged a refusal by the employer to hire an individual who used medical cannabis into a safety sensitive position on the basis of undue hardship. In this case, the undue hardship experienced by the employer was the lack of existing drug testing technology to determine impairment caused by cannabis use. ${ }^{50}$ The arbitrator took into consideration medical evidence that impairment by cannabis could last up to 24 hours after it had been consumed. ${ }^{51}$ The arbitrator held that in order to manage the safety risk posed by the use of medical cannabis, an employer must be able to measure the impact of the drug on the individual's work performance; hence, the inability to manage the risk of harm constitutes an undue hardship. ${ }^{52}$

It is at this juncture that privacy laws must also be considered.

49 Supra note 28. This decision is being appealed to the Supreme Court of Newfoundland and Labrador: Glen Whiffen, "N.L. Court Asked to Review Arbitrator's Dismissal of Man's Grievance for Being Denied Work Due to Medical Marijuana," The Central Voice (29 June 2018), online: <https://www.the centralvoice.ca/news/nl-court-asked-to-review-arbitrators-dismissal-of-mans-grievance-for-beingdenied-work-due-to-medical-marijuana-222394/>.

Tizzard, ibid at para 105 .

Ibid at para 104.

Ibid at para 169 . 


\section{PRIVACY}

In Canada, there is a patchwork of legislation and common law doctrine protecting the privacy of personal information that impacts the legal status of drug and alcohol testing and the permitted uses for information obtained through drug and alcohol testing.

The Personal Information Protection and Electronic Documents Act $t^{53}$ applies to federally regulated employers. There are three provinces that have enacted privacy legislation applicable to employees of provincially regulated private sector employers: British Columbia, ${ }^{54}$ Alberta, ${ }^{55}$ and Quebec. ${ }^{56}$ In general, privacy legislation in these jurisdictions regulates the collection, use, and disclosure of "personal information." Under PIPEDA and the privacy legislation in British Columbia and Alberta, there are provisions that permit employers to collect personal information from employees without their consent provided that the collection of the information is reasonable and the employees have prior notice of the collection of information and the purpose. ${ }^{57}$ While the collection from a breathalyzer, saliva, blood, or urine sample itself is not addressed by the legislation, the information that is revealed by the collection falls within the protection of the privacy statutes.

Provincially regulated private sector employers in other provinces are not subject to similar legislation, though employees can challenge the collection, use, and disclosure of their personal information by an employer using two approaches: (1) the common law tort of "intrusion upon seclusion," also commonly referred to as the tort of invasion of privacy; or (2) human rights or anti-discrimination legislation.

The tort of "intrusion upon seclusion" was first recognized by the Ontario Court of Appeal in 2012. ${ }^{58}$ This tort addresses "highly offensive" invasions of privacy, such as intrusions into "financial or health records, sexual practises and orientation, employment, diary or private correspondence." ${ }^{, 59}$ The right against invasion of privacy is not absolute and may give way to competing claims. ${ }^{60}$ Balancing this right is highly relevant to employers with strong competing interests in ensuring the health and safety of workers, and the security of their worksites.

Employers in the energy sector must balance individual rights to privacy and human rights against the employer's obligation to provide a safe workplace. Every Canadian jurisdiction has human rights legislation that prohibits discrimination in hiring and in the course of employment on the basis of prohibited grounds, including disability, as is discussed above. ${ }^{61}$ An individual seeking a remedy under human rights legislation in relation to discrimination on the basis of mental disability, such as a drug or alcohol addiction, or failure to accommodate a disability to the point of undue hardship, could also have complaints relating

SC 2000, c 5 [PIPEDA].

Personal Information Protection Act, SBC 2003, c 63 [BC PIPA].

Personal Information Protection Act, SA 2003, c P-6.5 [Alta PIPA].

Act Respecting the Protection of Personal Information in the Private Sector, RSQ c P-39.1.

See e.g. PIPEDA, supra note 53, s. 7.3; Alta PIPA, supra note 55, s 15(1); BC PIPA, supra note 54, s 13.

Jones $v$ Tsige, 2012 ONCA 32.

Ibid at para 72 .

Ibid at para 73.

See e.g. Alberta Human Rights Act, RSA 2000, c A-25.5, s 7. 
to a privacy breach arising from any associated drug and alcohol test or in the manner in which the disability was handled. ${ }^{62}$

In most circumstances, balance must be struck by taking into account the self-worth, dignity, and the right of an employee to safeguard his or her personal information (and be free from discrimination) and that of an employer to collect, use, or disclose that personal information to further the competing interest of workplace safety. The interest of an employer in collecting and using the results of a drug or alcohol test to support its health and safety objectives will be assessed for its reasonableness. In most cases, reasonableness will be determined by the notice the employee had of the possibility that a test would be taken (that is, the drug and alcohol policy), the manner in which the test was taken, including the justification for the test, the way in which the results were handled, and the treatment of any follow-up information relating to either a disability or recreational use.

The collection and use of the results of a drug and alcohol test is more likely to be found to be "reasonable" where the employer can demonstrate that the drug and alcohol test is a component of a broader workplace health and safety program, where testing is restricted to individuals in safety sensitive positions that require sobriety, and particularly where there is "cause" for the test (such as where there are bona fide reasons to suspect that an individual is impaired or where an individual has been involved in a serious incident). Prior notice of the test can be adequately provided through a properly implemented drug and alcohol policy. Consent to testing can be a term of employment.

Other types of testing, including random, pre-employment, and pre-access testing, may be reasonable, but the willingness of adjudicators to uphold these forms of testing has varied by jurisdiction, as will be discussed in greater detail throughout this article.

\section{COLLECTIVE BARGAINING}

In unionized environments, the employer retains the power to impose policies and rules on employees. Where employees face discipline for rule infringements, however, those rules must be both reasonable and consistent with the collective agreement.

The approach by adjudicators in Alberta prior to the Supreme Court of Canada's 2013 decision in Irving ${ }^{63}$ was arguably more employer friendly than the approach taken in Ontario. Historically, arbitrators in Ontario and other eastern provinces took the narrow view that a testing program can only be justified in limited circumstances, while arbitrators in Alberta were more likely to uphold a broad testing program, even without evidence that there was a substance abuse problem in the workplace. ${ }^{64}$ Human Rights Code, RSO 1990, c H.19 limited the employer's ability to conduct certain types of drug and alcohol testing.

Supra note 32.

Bantrel Constructors Co and UA, Loc 488 (Re) (2007), 162 LAC (4th) 122 at 146 (Arbitrators: PA Smith, W Johnson \& W Armstrong), aff'd 2007 ABQB 721, rev'd 2009 ABCA 84. 
The Supreme Court provided analysis of the reasonableness of drug and alcohol testing in Irving, in which it considered a grievance brought by the unionized employees of a paper mill in relation to their employer's policy instituting randomized breathalyzer testing for alcohol use by individuals in safety sensitive positions. The Supreme Court held that the reasonableness requirement for imposing rules in unionized workplaces required employers to draw a reasonable balance between their objectives (such as maintaining safety) and the harmful impacts of drug testing on employee rights (such as the right to privacy): "[a]ssessing the reasonableness of an employer's policy can include assessing such things as the nature of the employer's interests, any less intrusive means available to address the employer's concerns, and the policy's impact on employees. ${ }^{\prime 65}$

The Supreme Court upheld a consensus among labour arbitrators that, even in dangerous workplaces, the imposition of mandatory random testing for employees was "an unjustified affront to the dignity and privacy of employees unless there is reasonable cause, such as a general problem of substance abuse in the workplace." ${ }^{\prime 66}$

Following the Supreme Court's decision in Irving, determining what constitutes sufficient evidence of a "general problem in the workplace" has been contentious. The issue was recently examined in Suncor Energy Inc. and Unifor, Local 707A (Random Alcohol and Drug Testing Policy), $R e,{ }^{67}$ in which unionized employees grieved the employer's randomized drug and alcohol testing policy for safety sensitive positions at some of its Fort McMurray worksites. The employer took the position that the addiction problems at the site demonstrated a pervasive problem that is unparalleled in any case in Canada. ${ }^{68}$ This included over 2,200 drug and alcohol related incidents, including three fatalities, in a nine year period. ${ }^{69}$ Notably, in Irving, in which the random testing policy was not upheld, the employer relied on eight documented alcohol related incidents over a 15 year period. ${ }^{70}$

In Suncor, the majority of the Alberta Labour Relations Board upheld the Union's grievance. The Board found that the employer's allegations of a pervasive substance abuse problem were "unparticularized" and "unrefined," and concluded that the employer had not demonstrated sufficient safety concerns within the bargaining unit to justify random testing. ${ }^{71}$

The Alberta Court of Queen's Bench ordered the Board's decision quashed because it: (1) misapplied the balancing exercise of the employer's need to ensure safety against privacy interests as outlined in Irving; (2) only considered evidence that demonstrated substance abuse problems within the bargaining unit, ignoring the evidence of problems in the wider workplace; and (3) failed to consider all the relevant evidence. The Court ordered that the matter be sent back for a fresh hearing by a new panel. ${ }^{72}$

Irving, supra note 32 at para 27.

Ibid at para 6 .

(2014), 2014 CarswellAlta 457 (WL Can) (Arbitrators: Tom Hodges, David Laird \& Gwen Gray) [Suncor], rev'd 2016 ABQB 269 [Suncor QB], rev'd 2017 ABCA 313 [Suncor CA], leave to appeal to SCC refused, 37854 (14 June 2018).

Suncor, ibid at para 158 .

Ibid at paras 37, 53.

Irving, supra note 32 at para 13.

Suncor, supra note 67 at paras 253, 266, 271.

Suncor QB, supra note 67 at paras $69,79,88$. 
The Union appealed to have the Court of Queen's Bench decision quashed. In its decision, the Court of Appeal upheld the Queen's Bench decision, concluding in part that the Board had unreasonably ignored evidence of substance abuse in the broader workplace. By requiring the employer to adduce evidence particularized to members of the bargaining unit, the Board had set the Irving evidence threshold too high. The Court of Appeal concluded that the Irving test "calls for a more holistic inquiry into drug and alcohol problems within the workplace generally, instead of demanding evidence unique to the workers who will be directly affected by the arbitration decision." 73

In keeping with the Alberta Court of Appeal's decision in Suncor CA, the Ontario Superior Court recently released a decision favourable to employers seeking to establish robust drug and alcohol testing policies in ATU, Local $113 \mathrm{v}$. Toronto Transit Commission. ${ }^{74}$ In this case, the Court declined the Union's request for an injunction prohibiting the Toronto Transit Commission (TTC) from implementing random drug and alcohol testing pending the completion of grievance arbitration. The Court in TTC distinguished the case from Irving, finding that the evidence provided indicated a demonstrated workplace drug and alcohol problem at the TTC. ${ }^{75}$

Notwithstanding the specific caution to employers in unionized workforces with respect to relying on the management's rights clause versus bargaining for implementing testing, these decisions underscore the importance of thorough documentation of drug and alcohol problems in the workplace and the need for employers to take into account the full scope of the safety issues they can demonstrate prior to implementing testing.

\section{Justifications FOR Testing}

While some justifications for drug testing in the safety sensitive workforce are largely uncontroversial, others have been the subject of extensive litigation.

As confirmed by the Supreme Court of Canada in Irving, there is consistent arbitral jurisprudence establishing that, in dangerous workplaces, employers can demand that an employee submit to a drug test when "there is reasonable cause to believe that the employee was impaired while on duty" or "was involved in a workplace accident or incident." "The Supreme Court further noted that there is arbitral consensus that employers may require drug testing as part of an employee's negotiated return to work following an incident. ${ }^{77}$

Beyond "reasonable cause" and "post-violation" or "post-accident" testing, the legal standard for demonstrating the reasonableness of other justifications for proactive or

Suncor CA, supra note 67 at para 46.

2017 ONSC 2078 [TTC].

Ibid at para 139.

Irving, supra note 32 at para 5. See also the recent Ontario decision Airport Terminal Services Canadian Company v Unifor, Local 2002 (2018), 2018 CanLII 34078 at para 45 (Arbitrator: Daniel P Randazzo) [Airport Terminal Services], in which the arbitrator noted that a post-incident testing policy was overly broad and unreasonable because it was drafted to mandate drug and alcohol testing after every accident and incident (even potentially very minor occurrences), not just serious or significant events, without an analysis or balancing of an individual's privacy interests.

Irving, ibid. 
anticipatory drug testing remains challenging for Canadian employers, even for safety sensitive positions in dangerous workplaces.

\section{PRE-EMPlOyMENT TESTING}

In most Canadian jurisdictions (although not all, such as Alberta), the use of preemployment drug and alcohol testing as an applicant screening tool is not justifiable, and is in fact considered prima facie discrimination, on the basis that it does not establish or predict that the subject of the test will come to work impaired by drugs or alcohol, even if he or she tests positive for drugs or alcohol prior to starting employment. ${ }^{78}$ Given that a positive preemployment test result is not indicative of impairment in the workplace, the typical argument that testing is required for safety purposes may not be successful unless the employer can demonstrate that it has a sufficiently serious workplace drug and alcohol problem such that pre-employment testing is justified.

The jurisprudence suggests that testing for drugs and alcohol after a person receives a conditional offer of employment for a safety sensitive position may be permissible. ${ }^{79}$ Currently, an employer intending to implement pre-employment testing should ensure that any subsequent revocation of an offer following a positive test result does not violate applicable provincial human rights legislation. To that end, employers should not allow the candidate to commence safety sensitive duties prior to the test result being returned in order to mitigate against potentially violating human rights while upholding the integrity of the pre-employment test itself.

\section{PRE-ACCESS TESTING}

Pre-access drug and alcohol testing generally requires individuals to submit to a testing procedure immediately prior to being permitted on a job site.

In Mechanical Contractors Assn. Sarnia v. UA, Local 663, ${ }^{80}$ the Ontario Superior Court of Justice Divisional Court upheld a labour arbitration board ruling concluding that such a policy was not permissible. The employer, a Suncor contractor, complied with Suncor's policy requiring pre-access drug and alcohol testing for all contractors. The arbitrator found that pre-access testing was a violation of both the applicable collective agreement and the Ontario Human Rights Code. ${ }^{81}$ The arbitrator held that drug and alcohol screening was not

Specifically addressed in Entrop, supra note 26 at para 103. See also Ontario Human Rights Commission, "Policy on Drug and Alcohol Testing" (Toronto: OHRC, 7 April 2016), online: <www. ohrc.on.ca/sites/default/files/Policy\%20on\%20drug\%20and\%20alcohol\%20testing_revised_2016_ac cessible 1.pdf.

79 See e.g. Weyerhaeuser Co v Ontario (Human Rights Commission) (2007), 279 DLR (4th) 480 (Ont Sup Ct J (Div Ct)). See also Alberta Human Rights Commission, "Pre-employment Medical Testing" (15 March 2010), online: $<$ https://www.albertahumanrights.ab.ca/employment/employer_info/hiring/Pages/ pre-employment_medicals.asp $\mathrm{x}>$, which demonstrates that even in Alberta where pre-employment testing has not been virtually outlawed like in other jurisdictions, the guidance still instructs employers that a conditional offer ought to be made in order for the collection to be reasonable. 
a BFOR because it "casts too broad a net" by capturing employees who were not impaired or performance deficient and who posed no workplace health and safety risk. ${ }^{82}$

This case remains the leading precedent on policies which include pre-access testing in Ontario and is instructive for other jurisdictions. It is clear that the arbitrator leaves open the possibility that pre-access testing may be justifiable where there is evidence of a health and safety problem in the workplace linked to alcohol and drug use. It is important to note that the analysis in the case was limited to circumstances involving drug testing technology that fails to capture current impairment or performance deficiency, as well as any information that would indicate the extent of the individual's use of the drug (that is, whether a person is a casual user, drug dependent, and so on). Current laboratory testing technology performed to a defensible standard is highly reliable and specific, and serves to signify a potential risk of impairment or likely impairment. As broader acceptability of the current testing methods or a revised set of testing thresholds are adopted to signify an actionable workplace risk, it is possible that drug testing methods will drive different outcomes in these types of cases. New technology and methodology in this space will require considerable scientific acceptance and due diligence to withstand the legal scrutiny that the current litigiously resilient methods of testing offer to employers.

\section{MANDATORY RANDOM TESTING}

As Irving indicates, mandatory random drug and alcohol screenings will often be found to be contrary to human rights legislation or impermissible under a collective agreement. There are also right to privacy arguments that can be made in opposition to random testing where there is no justification for implementing the program. TTC and Suncor CA may, however, represent a renewed willingness to find that some circumstances justify random testing.

Even in workplaces where mandatory random screening is justifiable, it is important that the testing technology and methodology selected by the employer be able to detect present or reasonable risk of impairment with integrity. To detect risk of impairment, the test must be forensically sound and limited to biological mediums that reflect recent (rather than past, for example, hair testing) drug or alcohol usage and the results must be returned prior to the employee resuming work in a safety sensitive position.

In Entrop ${ }^{83}$ an employee challenged Imperial Oil's drug and alcohol testing policy. The Ontario Court of Appeal upheld the Ontario Human Rights Commission's finding that random drug testing discriminated on the basis of actual or perceived substance abuse. ${ }^{84}$ The Court notably found that randomized drug testing by urinalysis was not a BFOR, because the test detected past drug use (which would have minimal impact on workplace safety), as well as present drug use. By contrast, the Court held that alcohol testing constituted a BFOR because breathalyzer tests detected present impairment. ${ }^{85}$ 
In Nanticoke, ${ }^{86}$ the Ontario Court of Appeal again considered the Imperial Oil drug screening policy. Following Entrop, Imperial Oil had instituted saliva testing for cannabis. The test used could detect present impairment but the results were not available for several days because they required analysis at a laboratory in Houston. The Court upheld the arbitration board's finding that such delayed results did not promote safety because potentially impaired employees were sent back to work pending the employer's receipt of the test results. ${ }^{87}$

The Ontario Court of Appeal decisions in Entrop and Nanticoke stand in contrast with the decision in Alberta (Human Rights and Citizenship Commission, Director) v. Kellogg Brown $\&$ Root (Canada) Co. ${ }^{88}$ where the Alberta Court of Appeal upheld pre-employment testing for cannabis. The Alberta Court of Appeal held that the effects of cannabis usage persisted for a number of days, and that therefore even casual users of cannabis posed a safety risk and the test result essentially indicated a risky lifestyle. ${ }^{89}$

These cases tend to narrowly define impairment, conflating it with the individual's stronger, initial intoxication and the period of time during which the individual experiences the most obvious symptoms of recent use. Adjudicators seem to have anchored their understanding of cannabis impairment on alcohol impairment, thereby failing to fully take into account the broader neurocognitive impairments that continue beyond the initial period of intoxication when an individual uses cannabis. A recognition of the continued impairment of executive function and other deficits following this initial period should support a finding that a positive drug test serves to reasonably indicate an actionable risk that an individual is impaired and should not work in a dangerous or safety sensitive position.

The Canadian Nuclear Safety Commission, under the Nuclear Safety and Control Act, ${ }^{90}$ has recently passed a regulatory document entitled "Fitness for Duty, Volume II: Managing Alcohol and Drug Use." ${ }^{\prime 11}$ This document is the first in Canada to obligate Canadian employers to drug test employees for all of the justifications explored herein, including random testing. Its contents are precedent setting in a number of ways: first, it clearly indicates that security sensitive and safety sensitive occupations may necessitate fitness for duty as a BFOR; secondly, it reinforces that current justifications for testing are suitable; and lastly, it shows that the defensible methods commonplace in Canada are both an acceptable and a practical means of identifying workplace risk.

\section{IMPLICATIONS FOR EMPLOYERS IN THE ENERGY SECTOR}

It is estimated that over 500,000 drug tests are performed each year in Canada for purposes relating to employment and that this number is increasing..$^{92}$ An employer seeking

\footnotetext{
Supra note 32.

Ibid at para 72 .

2007 ABCA 426.

Ibid at paras 33-34.

SC 1997 , c 9.

Canadian Nuclear Safety Commission, "Fitness for Duty, Volume II: Managing Alcohol and Drug Use," Regulatory Document 2.2.4, v 2 (Ottawa: CNSC, January 2018).

Based on data presented at the 2018 International Forum for Drugs and Alcohol Testing. See also Ontario Human Rights Commission, "Drug and Alcohol Testing - Frequently Asked Questions," online: $<$ www.ohrc.on.ca/en/drug-and-alcohol-testing---frequently-asked-questions $>$.
} 
to satisfy its obligations under human rights and privacy legislation while justifying a testing program for workplace health and safety should ensure its policy and procedures include the following elements:

(1) Safety Sensitive Positions: in general, testing will be more likely to be a BFOR where the nature of the work performed by the employee subject to the test is truly safety sensitive. Each position should be evaluated to determine if it is safety sensitive. In developing a job description for a new position, safety sensitive tasks should be clearly identified.

(2) Justifications for Testing: the various justifications for testing that are or may be implemented should be identified in the policy along with a description of the basis for each. Employers should further identify the scope of drugs being tested and the respective cut-off thresholds, and similarly the cut-off thresholds for alcohol levels.

(3) Testing Mediums, Methods, and Cut-off Levels: the only three acceptable biological mediums or specimen types for testing in Canadian workplaces are breath (alcohol), urine, and oral fluid..$^{93}$ Taking action on results of testing requires forensic integrity of both the instrumentation used to perform the testing, as well as the process for collecting the specimens and conducting the testing. Cut-off levels should be established at arm's-length by either the Department of Health and Human Services or a Canadian authority, if available. Employers should be aware that adhering to the established cut-off levels is often a limiting factor in the use of POCT and that no adverse employment action should be taken unless the results can be verified. The employee's removal from the workplace pending the employer's receipt of the testing results is not regarded as punitive or suggestive of a violation by the employee. Instead, the action will be considered one part of the employer's routine procedure to ensure the safety of the worker and workforce during the investigation process, particularly if conducted in accordance with the applicable written policy or procedure.

(4) Self-Disclosure Mechanism: there should be a procedure for an employee or prospective employee to proactively disclose a substance dependency or other disability without fear of reprisal. The procedure should direct the employee to the applicable accommodation policy and procedure.

(5) Disciplinary Consequences: since these policies are part of the overall safety due diligence program, they should outline the disciplinary consequences that can result from policy breaches. However, attention must be paid to any potential dependency issues and human rights obligations.

(6) Consistent Implementation: all policy violations should be followed by removal from safety sensitive work and, where appropriate, an arm's-length evaluation of whether the individual has substance dependency issues in order to determine 
whether there are accommodation obligations and to assist with determining the process for a safe return to work.

(7) Compliance with Third Party Policies: for employers who are part of joint ventures or that provide services to other companies on their sites or at their camps, there should be a provision that alerts employees to the possibility that they may need to comply with other companies' drug and alcohol policies regarding site access or performing other services under those contracts. Employers should first review the other entities' policies to ensure that they are reasonable.

These elements are found in most energy sector employer policies. However, while many employers have already updated their policies to address medical cannabis, with the legalization of recreational cannabis, existing policies will need to be further revisited as most identify drugs as "illicit" or "unlawful." Employers must also consider the language they use in describing the objectives in their policies, for example, by ensuring that there is a focus on risk reduction and identification of the risk of impairment versus exclusively a focus on identifying actual current impairment. Testing methods that are presently available (for example, urinalysis, oral fluid, and blood testing) do not show current impairment for drugs, rather they approximate the risk or likelihood of impairment. The acceptability of these variations, primarily dependent on the biological medium chosen and respective testing cut-off threshold, will likely be impacted by legalization and will be discussed in further detail below.

\section{Medical Cannabis Considerations}

\section{A. Medical Cannabis at the Workplace}

Lawful access to medical cannabis evolved from Ontario jurisprudence, $R$. v. Parker, ${ }^{94}$ adjudicated the year preceding the first 2001 Marihuana Medical Access Regulations, ${ }^{95}$ subsequently repealed on 31 March 2014 and replaced with the Marihuana for Medical Purposes Regulations, ${ }^{96}$ repealed on 24 August 2016 and replaced with the current Access to Cannabis for Medical Purposes Regulation. ${ }^{97}$ With each revision to the medical cannabis regulations, medical accessibility and treatment options for patients has been expanded and decentralized away from the federal government's direct oversight. It is of note that the initial medical accessibility to cannabis was not the consequence of endorsement by national medical authorities like the Canadian Medical Association, Federation of Medical Regulatory Authorities, nor Health Canada. Instead, the legal community's level of evidence necessary for acceptability and the medical community's level of evidence necessary for acceptability differed. The medical authorities' broad support of both the past and present regulations is limited due to the lack of conclusive clinical quality research to support evidence based treatments for the totality of the available medical applications under the Access to Cannabis for Medical Purposes Regulation. At this time, cannabis is not an approved drug or medicine according to Health Canada and remains legally accessible by provision of a medical 
authorization and is obtained through a licensed producer. ${ }^{98}$ The intent of the aforementioned is not to discredit the suitability or validity of cannabis as a medical treatment, but to highlight the limitations of the current state of available medical evidence to guide any occupational opinion, by even the most qualified medical professionals, on the topic of work clearance and fitness for duty.

There have been mixed reviews over whether the use of medical cannabis should be prohibited for employees performing safety sensitive work. However, recent case law supports employees using medical cannabis in safety sensitive work where it can be shown that the use is not impairing.

Based on reports from both Canadian and United States occupational medicine authorities, an employer may have a reasonable basis for requiring a worker's abstinence from cannabis both on and off-duty, where the employee is unable to provide sufficient medical evidence to demonstrate that he or she will not be impaired at work. ${ }^{99}$ From one perspective, this denial may be justified by the lack of sufficiently credible evidence based authoritative directives by occupational medicine authorities, the lack of pharmacokinetic evidence to support the medical clearance, and the inconsistency of such clearance as compared to occupational health standards for the applicable industry, such as rail, enforcement, and aviation - all of which are complex and dangerous occupations. ${ }^{100}$ However, from another perspective, it has been found in recent jurisprudence that medical cannabis was consumable in a manner that does not render the employee unfit for safety sensitive work. It is worth noting that these determinations, as in most cases, were limited to the evidence provided and the nuances of the applicable policies.

In a recent decision from Ontario, an arbitrator heard medical evidence respecting cannabis impairment and concluded that a grievor whose urine test had been positive for cannabis use and had not consumed cannabis for at least 12 hours before commencing work on the date of the incident, was not impaired. ${ }^{101}$ The arbitrator relied upon the decisions in Canadian Pacific Railway and Teamsters Canada Rail Conference (Gardippie), Re ${ }^{102}$ and Canadian Pacific Railway and Teamsters Canada Rail Conference (Reid), Re ${ }^{103}$ in which the arbitrators found that a positive urine test is not conclusive of impairment. The arbitrator went on to comment on concerns respecting the use of cannabis, including that the medical experts in the case agreed that the strain of cannabis used is an important consideration

Canadian Medical Association, “CMA Response: Health Canada’s Medical Marihuana Regulatory Proposal" (28 February 2013), online: <https://www.cma.ca/Assets/assets-library/document/en/ advocacy/Proposed-Medical-Marihuana-Regulations_en.pdf>; Letter from Heidi Oetter, President of the Federation of Medical Regulatory Authorities of Canada, to Health Canada (27 February 2013), online: <www.fmrac.ca/wp-content/uploads/2014/02/SubmissiononMedicalMarihuana.pdf $>$; Health Canada, Information for Health Care Professionals, supra note 7.

Jennan A Phillips et al, "Marijuana in the Workplace: Guidance for Occupational Health Professionals and Employers" (2015) 57:4 J Occupational \& Environmental Medicine 459; Robert S Goldsmith et al, "Medical Marijuana in the Workplace: Challenges and Management Options for Occupational Physicians" (2015) 57:5 J Occupational \& Environmental Medicine 518; Charl Els, Aditi Amin \& Sebastian Straube, "Marijuana and the Workplace" (2016) 7:4 Can J Addiction 5. Medical Rules Handbook (Ottawa: RAC, May 2018), online: <https://www.railcan.ca/wp-content/ uploads/2016/10/Canadian_Railway_Medical_Rules_Handbook_EN.pdf>; 1 CFR tit 49 § 40 (2017). Airport Terminal Services, supra note 76 at para 28.

102 (2014), 2014 CarswellNat 929 (WL Can) (Arbitrator: Christine Schmidt). 
because it could have a significant effect on the window of impairment. The arbitrator concluded:

Finally, the expert evidence and literature are inconclusive when it comes to determining the window of impairment which varies depending on the strain, dosage and the user and as such, extreme caution should be taken when an employee is taking medicinal marijuana in a safety sensitive workplace. ${ }^{104}$

In French v. Selkin Logging, ${ }^{105}$ the grievor, a cancer survivor who admitted to regularly smoking cannabis at work to manage pain, was operating a company vehicle and collided with a moose. Mr. French did not have a permit for medicinal cannabis and worked in the logging industry. Although no evidence was presented that French's ability to work safely was actually impaired, the British Columbia Human Rights Tribunal concluded that the employer's "zero tolerance policy" was a BFOR. ${ }^{106}$ The employer was not required to accommodate French's smoking of cannabis without medical authorization. ${ }^{107}$

By contrast, in Calgary (City of) v. Canadian Union of Public Employee (CUPE 37), ${ }^{108}$ the opposite conclusion was reached in respect of a heavy equipment operator who used medically authorized cannabis before going to bed. The matter was referred to arbitration when the employer removed the grievor from his position upon learning of his cannabis use and accommodated him in a non-safety sensitive capacity. In arbitration, it was found that there was no evidence that the cannabis use had any impact on the grievor's ability to perform safety sensitive duties in a safe manner or that he had ever exhibited signs of impairment on duty. Dependency was not established. The remedy was to reinstate the grievor as a heavy equipment operator with back pay, subject to a protocol for handling the employee's cannabis usage. ${ }^{109}$

Any determination of the options and extent of accommodation required for an employee using medical cannabis in a safety sensitive occupation will require an analysis of the strain, dosage, timing of use, alternative available treatments, and factors specific to the user.

Employers must, therefore, distinguish three scenarios:

1. An employee using cannabis recreationally or without proper medical documentation or justification, in which case, there is no duty to accommodate the employee;

2. An employee using cannabis in accordance with proper medical documentation and is therefore unfit for duty due to this use. In many situations, this employee may be entitled to accommodation in a non-safety sensitive position; and

(2015), 2015 CanLII 61756 (Arbitrators: Tom Hodges, William Armstrong \& Julien Landry) [CUPE]. See also Wilson v Transparent Glazing Systems (No 4), 2008 BCHRT 50. 
3. An employee using cannabis in accordance with proper medical documentation and who is willing to pursue an alternative effective treatment that does not pose a workplace risk. The employer may not be able to remove this employee from the safety sensitive position.

Since the federal government has legalized cannabis for recreational use, employers must consider the extent to which they need or prefer to restrict the use of recreational cannabis both on and off work duty.

\section{Recreational Cannabis Considerations}

Many drug and alcohol policies allow for limited social drinking during the workday for specific, non-safety sensitive employees, or at social host parties or events that include drinking during off-duty hours. In all cases, employees are expected to come to work and remain fit for work throughout their shift. Once cannabis is legalized, its social use will become more acceptable, and employers will need to decide whether they will continue to prevent any such use during the work day or at company events. Employers will need to adapt their policies and practices with recreational use in mind, particularly with regard to the presence of metabolites in an employee's system due to off-duty recreational use.

It is conceivable that more employers will move toward mandating oral swab testing or other methods, like urine, for identifying risk or risk of impairment. Appreciating that the current thresholds may change, the employee will regardless have to remain off work for typically four or more days if the final result is positive, or negative with a safety advisory (non-negative, not conclusive, and so on). Laboratory testing with forensic integrity requires two technical methods, screening and confirmation, as well as a discussion between the employee and a physician certified as an MRO to verify the final outcome of the result directly with the employee prior to the employer notification. ${ }^{110}$ Safety sensitive employers who currently use urinalysis for drug testing may have to change their objectives for weeding out candidates following pre-employment tests or releasing employees following positive for cause tests, where there is no dependency, based on test results that show risky lifestyles (that is, show potential past impairment, and current risk of impairment) due to the anticipated increase in use now that cannabis is legalized. Similarly, employees in the past have often disclosed or been diagnosed with dependency following a drug test when assessed by a substance abuse professional, which invokes the employer's duty to accommodate. The question of interest to employers is whether an employee who has a positive test result will maintain that their use is non-recreational. Clearly, the net result for these employees is potential job protection, if the use was due to dependency, versus job loss, if the use was recreational.

While the type of drug and alcohol policy implemented for addressing consequences of use will be key, it would not be surprising if employees begin to challenge the types of tests used for privacy reasons, particularly in jurisdictions with specific privacy legislation, given that the substance will be legalized. An employee's argument could be that the test results are overly broad and fail to achieve the objective of the policy (because they do not show 
current impairment) and therefore the testing is an unreasonable collection of personal information. This highlights again the importance that employers must place on risk of impairment or risk reduction as the primary intent of a fit for duty policy.

Employers in the energy sector should approach drug testing as a reasonable risk identification tool within a broader program aimed at removing risk, while retaining the individual. Attempting to establish current impairment is fraught with peril, as there is no biological test to date that measures current impairment for cannabis - nor is such a test necessary when the objective is risk reduction. What is important is that to be fit for duty, there should not be any objective evidence of recent drug use that surpasses the accepted thresholds. The available methods, including testing thresholds, are reasonable indicators of risk of impairment and the lingering neurocognitive effects of cannabis - what is skewed however, is the understanding of the acute period of intoxication, which is, at this stage, likely too narrow a view for the safety interests of the energy sector.

\section{Is a Zero Tolerance Policy ACCeptable?}

In addition to being exposed to potential civil liability, employers risk incurring criminal charges pursuant to section 217.1 of Canada's Criminal Code should they be found to have failed to "take reasonable steps to prevent bodily harm to [a person over whom they undertake, or have the authority, to direct how that person does work or performs a task], or any other person, arising from that work or task." 111

Across Canada, employers have a general duty under occupational health and safety legislation to take all precautions reasonably necessary for the protection of workers. In the event of a workplace incident resulting in a worker's injury or illness, an employer may have a defence to a breach of a statutory health and safety obligation where it can show that it has been duly diligent in taking all precautions reasonably necessary to ensure the safety of a worker in the circumstances.

Faced with these risks, zero tolerance policies may seem like attractive measures to employers with safety sensitive operations. These policies express that there will be zero tolerance for on-the-job consumption, possession, sale, or distribution of drugs and alcohol, and accordingly, a breach of the policy will result in dismissal. However, employers must consider whether the policy has the potential to result in discrimination or failure to accommodate an employee with a dependency. Accordingly, zero tolerance testing policies are only likely to withstand judicial review in limited higher risk circumstances.

Zero tolerance policies also need to clarify whether they are addressing past or present use. The Canadian Human Rights Tribunal phrased the issue as follows in Milazzo v. Autocar Connaisseur Inc.: "[t]he question then arises: Zero tolerance of what? Zero tolerance of employee impairment? Or zero tolerance of employees having drug metabolites in their systems?"112 
Case law in respect of zero tolerance policies is largely unsettled and will likely evolve significantly following the legalization of cannabis and advances in technology that can be used to test for current impairment.

Most recently, the Ontario Superior Court's decision in TTC suggests that a less stringent, threshold based policy is more likely to be upheld upon review. ${ }^{113}$ Under the TTC's "Fitness for Duty Policy," a positive oral fluid drug test was one in which a sample tested contained a drug at or above specified cut-off levels. The thresholds adopted by the TTC were higher than those in the Mandatory Guidelines for Federal Workplace Drug Testing Programs drafted by the US Substance Abuse and Mental Health Services Administration (SAMHSA). ${ }^{114}$ The Court observed that the TTC's relatively high cut-off levels, along with other factors, made it likely that the person who tested positive was indeed impaired when tested. Therefore, "the TTC Policy reasonably ensures that only employees who are most likely acutely intoxicated due to recent consumption of marijuana will test positive." 115 After considering all the evidence, the Court was satisfied that random testing would increase public safety because "the likelihood that an employee in a safety critical position, who is prone to using drugs or alcohol too close in time to coming to work, will either be ultimately detected when the test result is known or deterred by the prospect of being randomly tested." $" 116$

Ultimately, TTC indicates that an appropriately selected impairment threshold supported by third-party research, such as that of SAMHSA or the Canadian Medical Association, ${ }^{117}$ is more likely to survive judicial review than zero tolerance policies, which are at risk of being deemed unreasonably broad or unclear.

In any event, it is essential to recognize that drug testing in general is not "zero tolerance," as a laboratory responsible for testing will have a threshold of an acceptable presence of any given drug. This threshold is called a "concentration cut-off level." The purpose of this cutoff level is to preserve the integrity of the testing by reasonably accounting for passive or environmental exposure.

\section{Policies ReQuiring Disclosure OF SUBSTANCE DEPENDENCY}

Courts have readily acknowledged that alcohol and drug testing engages an individual's right to privacy. ${ }^{118}$ As discussed above, employee privacy interests must be considered within the context of an employer's work environment, including an employer's obligation to maintain a safe work environment. An employee's right to privacy does not necessarily override an employer's health and safety obligations. ${ }^{119}$ This balancing act is particularly

See TTC, ibid at para 23; United States, Substance Abuse and Mental Health Services Administration, "Mandatory Guidelines for Federal Workplace Drug Testing Programs" (23 January 2017) 82:13 Federal Register 7920. 
important in respect of safety sensitive positions, where safety concerns that are known to employees "will reasonably diminish their expectation of privacy concerning their drug and alcohol consumption." 120

The tension between privacy and safety is highlighted in decisions regarding policies that require an employee to disclose drug or alcohol use prior to committing a policy breach.

\section{A. Disclosure}

\section{Discipline For Failure To Disclose Substance Use}

The Supreme Court of Canada has recently upheld an Alberta employer's decision to terminate an employee for breaching its drug and alcohol policy despite the employee's dependency disability. In Stewart (discussed in Part III.B.1, above), the Supreme Court affirmed the Alberta Human Rights Tribunal's finding that the employer could terminate an employee for testing positive following an incident. ${ }^{121}$ This case directly addressed the question of whether an employer can discipline an employee who failed to disclose substance dependency.

The employee worked in a mine operated by the Elk Valley Coal Corporation. The duties of his position included driving a loader. The employer implemented a policy requiring that employees disclose any dependence or addiction issues before any drug related incident occurred. If an employee disclosed such an issue, the employee would be offered an opportunity to receive treatment, however, an employee who failed to disclose would be terminated in the event that they are involved in an accident and subsequently test positive for drugs. The employer had a policy that provided for post-incident testing. ${ }^{122}$

The employee did not disclose to his employer that he was using cocaine on his days off from work. After being involved in an incident with his loader, the employee tested positive for drugs. The employer terminated his employment. ${ }^{123}$

The Supreme Court of Canada agreed with the Alberta Human Rights Tribunal that the employee's termination was due to non-disclosure rather than the employee having an addiction. The Supreme Court concluded that the employee's denial about his addiction was irrelevant to the case because the employee had the capacity to come forward to disclose his drug use and to make rational choices regarding the disclosure of his drug use. ${ }^{124}$

Allowing disclosure to be made to a designated medical authority is encouraged to further protect employee privacy while encouraging self-reporting. As explained by an arbitrator in Vancouver Shipyards Co. and U.A., Loc. 170 (Re):

$\begin{array}{ll}120 & \text { TTC, supra note } 74 \text { at para } 40 . \\ 121 & \text { Supra note } 43 . \\ 122 & \text { Ibid at para } 1 . \\ 123 & \text { Ibid at para } 2 . \\ 124 & \text { Ibid at para } 38 .\end{array}$


In particular, employees must be seen as entitled to require that the disclosure be limited to appropriate medical authorities employed or retained by the Employer so that the goal of assessing whether any proactive intervention required to protect the interests of both the employee and the Employer can be achieved without compromising the employee's right of privacy beyond the level needed to protect the Employer's right of disclosure.

In an age when drug and alcohol addiction is routinely seen as a disability that requires accommodation by employers, the balancing of interests implicit in the approach dictated in the legislation and the relevant Court and arbitral decisions requires that disclosure be limited to the level necessary to permit the Employer to respond objectively. It is implicit that an employee who has a current drug or alcohol problem must disclose that fact and thus permit managerial and supervisory employees to be informed to ensure that the safety aspects of an employer's operation are addressed. By contrast, disclosure of past problems that are acknowledged to have been in remission for up to six years favour a restriction on the level of reporting. In particular, the interests of the Employer would be preserved if disclosure is made to a designated medical authority so that the implications of the past problem and the possibility of a relapse can be assessed and accommodated. $^{125}$

Employers should emphasize that confidentiality of self-disclosure will be maintained to the extent possible in keeping with the obligation to manage the employee and the workplace. Employers should utilize a qualified third-party substance abuse professional to assess for disability following any post-incident testing and related requirements, such as a return to duty drug test for a safe return to work and follow-up unannounced testing for ongoing compliance and deterrence of relapse.

Regarding recreational use, it can be anticipated that most employers of safety sensitive employees will maintain that employees cannot use cannabis in a manner that makes them unsafe or unfit for duty; therefore, under the current state of the law, self-disclosure of recreational use will be irrelevant because a positive test will likely then have disciplinary consequences notwithstanding the disclosure. However, as technology evolves or as the law develops, or both, employers could see a shift in acceptable levels of off-duty use that does not impact safe performance, which again can result in privacy challenges, grievances, or wrongful dismissal claims, unless the employer's policies, practices, and testing standards shift as well.

\section{DISCIPLINE FOR FAILURE TO REPORT Substance USE By a COLlEAgue}

Employers may consider implementing provisions in their policies that encourage (or even require) employees to report bona fide suspicions or knowledge of substance use by a colleague that may impact safe performance of job duties, with appropriate references to the general obligations of supervisors and workers under the applicable occupational health and safety laws.

It is critical that such a discipline policy be flexible so that each case is evaluated on its merits. For example, it may be difficult to demonstrate that an employee who suspected or 
was aware of a colleague's substance use should be severely disciplined for failure to report. However, where a colleague is found to have been aiding, encouraging, or was otherwise culpable in a preventable safety incident and there is clear evidence of the employee's knowledge, employers should preserve discretion to apply more severe discipline as part of their overall safety program.

In addition to providing for discipline relating to a failure to comply with the policy by reporting suspicions of substance use, employers may also want to consider having a workplace policy that provides the potential for discipline for employees who have reported substance use in bad faith or who are otherwise dishonest in their reporting.

Regarding recreational cannabis use, employers will have to consider the extent to which they can expect or require an employee to report off-duty use, which may be witnessed at a social gathering or similar outing unrelated to the workplace. At the very least, employers ought to emphasize the requirement to report suspicions that a co-worker is unfit for duty based on observations at the time of reporting. Whether an employer requiring reports of offduty recreational use is reasonable or too far-reaching (for example, due to privacy concerns) is to be decided by our courts and regulators.

\section{CONCLUDING REMARKS: WhAT TO EXPECT FroM FUTURE LEGISLATION}

Few countries have legalized cannabis, placing Canada and its employers at the forefront of establishing an approach to address the associated risks in workplaces, and more broadly in society. The legalization of recreational cannabis in 2018 has caused regulators to consider the implications for occupational health and safety and related legislation. ${ }^{126}$ To date, plans for additional or amended legislation vary across jurisdictions. City of Calgary bylaws have been considered that would prevent use in most public places, however local police have indicated that these bylaws would be nearly impossible to enforce. ${ }^{127}$

In Ontario, Bill 174 received Royal Assent in December 2017 and prohibits consumption of cannabis in a workplace within the meaning of the Occupational Health and Safety Act, ${ }^{128}$ with exceptions for persons who consume it for medical purposes in limited occupational settings. ${ }^{129}$

At the federal level, see Government of Canada, Framework for Legalization and Regulation, supra note 18 at $28-29$.

Postmedia News, "From Calgary City Hall: Should Cannabis Use be Limited to Homes?" Calgary Herald (3 April 2018), online: < https://www.calgaryherald.com/news/local-news/live-from-calgary-cityhall-council-debates-ban-on-cannabis-use-in-public $>$.

Ont OSHA, supra note 19.

Bill 174, An Act to enact the Cannabis Act, 2017, the Ontario Cannabis Retail Corporation Act, 2017 and the Smoke-Free Ontario Act, 2017, to repeal two Acts and to make amendments to the Highway Traffic Act respecting alcohol, drugs and other matters, 2nd Sess, 41st Leg, Ontario, 2017, cl 11 (assented to 12 December 2017), SO 2017, c 26. 
By contrast, Alberta has committed to reviewing occupational health and safety regulations and to working with employers, labour groups, and workers to ensure that current rules continue to address cannabis impairment issues. ${ }^{130}$

One may speculate that, given this recent interest in the regulation of legalized cannabis use, industry groups and regulators of dangerous, safety sensitive workplaces will strive for an approach similar to that of the Canadian Nuclear Safety Commission to make the implementation of testing programs mandatory. However, in safety sensitive industries that fall short of dealing with nuclear or other extremely dangerous goods with high potential of catastrophic damage, it remains to be seen whether our regulators would actually go that far. It is possible that occupational health and safety laws will be amended to address all intoxicating substances over time.

As we have described above, Health Canada has acknowledged that THC in cannabis impairs an individual's ability to drive safely and to operate equipment, and can also potentially increase the risk of falls and other accidents. THC affects an individual's executive functions, including coordination, reaction time, and ability to pay attention, make decisions, and judge distances. Health Canada has recognized that impairment from cannabis can last for more than 24 hours after use, well after the symptoms associated with recent use may have faded. ${ }^{131}$

Cannabis use is expected to rise, and employers in the energy sector are left in the position of having to try to pre-empt and prevent the consequential workplace risks. To manage the added workplace risk imposed by the legalization of cannabis, employers need to understand that impairment from cannabis is not the same as impairment from alcohol. Cannabis impairment presents differently, is more subtle, and lasts longer than alcohol — often unknowingly to the user. Cannabis as a medicine is also not risk free, despite the many low THC formulations which may be available. Scientific research and understanding regarding strains, dosages, and their corresponding effects have yet to become sufficiently enhanced. The implications of the conclusions by research authorities regarding cannabis in the workplace are also significant. The conclusions point out that focusing on just the "high" or acute impairment, as Canadians tend to do, is insufficient. Research serves to reinforce existing approaches that focus on managing risk versus impairment — enabling employers now more than ever to adopt current technology and best practice standards that are both trustworthy and well-established. What is critical, however, is to ensure that any standards that are adopted are applied correctly, in a fair and reasonable manner, and in accordance with the current legal landscape.

Employers in the energy sector will have to ensure that they are aware of and stay current on anticipated legal, scientific, and technological advancements relating to cannabis in order to ensure they are onside the law while remaining an attractive, safe place to work. Employers are well aware of their legal obligation and shared responsibility to enforce workplace safety, including implementing adequate safety measures to prevent harm. While 
all employees are expected to be fit for duty, individuals in positions with heightened risks are justifiably held to a higher standard. Increasingly, these standards include using drug and alcohol testing as a reasonable deterrent and compliance tool; and, for these tools to work properly, they hinge on a balancing of several interests, where safety considerations must be real and tangible.

With legalization, current policies and practices will need to be reviewed to address fitness for duty; social and other potentially acceptable instances of cannabis use (or the continued prohibition of cannabis use at any event related to the company); and the specific language used in the policy may need to be adjusted as it is likely that cannabis is subsumed in the category of illicit drugs. Testing components of policies will have to adapt to, and develop with, the anticipated evolution of drug testing methodologies and case law. The energy sector, with its many safety sensitive occupations will be among those industries that lead the way in navigating the new, legal landscape that will make waves across Canada, and beyond, if and when cannabis is legalized. Understanding cannabis and its impacts on workplace safety, along with balancing the associated human rights and privacy rights, are the first steps in promoting a safe future for our Canadian workplaces in tandem with the groundbreaking likelihood that using cannabis will soon become an acceptable and common social norm. 